\title{
Hardwired to attack. Candidates' personality traits and negative campaigning in three European countries
}

\author{
Alessandro Nai ${ }^{1}$ (D) Anke Tresch ${ }^{2} \cdot$ Jürgen Maier ${ }^{3}$
}

Accepted: 28 October 2021 / Published online: 1 January 2022

(C) The Author(s) 2021

\begin{abstract}
A growing body of studies shows that the reasons for competing candidates to "go negative" on their opponents during elections - that is, attacking their opponents instead of promoting their own programs or ideas stem from strategic considerations. Yet, existing research has, at this stage, failed to assess whether candidates' personality traits also play a role. In this article, we bridge the gap between existing work in political psychology and political communication and study to what extent the personality traits of competing candidates are linked with their use of negative campaigning strategies. We rely on candidate survey data for recent elections in three countries-Germany (2017), Switzerland (2019), and Finland (2019). The data includes self-reported measures for candidates' "Big Five" personality traits (extraversion, agreeableness, conscientiousness, neuroticism, openness) and the the use of attacks towards their opponents during the campaign. Controlling for the usual suspects driving the use of negative campaigning we show that this latter is associated with low agreeableness and (marginally) with high extraversion and low conscientiousness. The role of personality for the focus of an attack (issue vs. character attacks) is somewhat less clear-cut. All in all, kinder and more stable candidates tend to go less negative; when they do, they tend to stay away from characterbased attacks and somehow focus on issues.
\end{abstract}

Keywords Candidate personality · Big Five · Negative campaigning · Issue attacks · Character attacks $\cdot$ Candidate survey $\cdot$ Comparative political communication






\section{Introduction}

Negative campaigning is an important component of modern elections (e.g., Geer 2006; Lau \& Pomper 2004)- but it can potentially have 'corrosive' effects on democracy, for example, polarizing the electorate and depressing turnout (e.g., Ansolabehere et al. 1994; Iyengar et al. 2012). Over the past 30 years, research on negative campaigning has rapidly grown. Initially focused mostly on the US case, research has increasingly shifted its focus to (Western) European multi-party systems. Yet, this shift suffers from at least three shortcomings. First, given the role of parties as dominant campaign actors in Western European democracies, most studies focus on attack behavior by parties rather than candidates (e.g., Elmelund-Præstekær 2008; Stückelberger 2021; Walter 2014; Walter \& van der Brug 2013). When attention is paid to candidates, the focus is mostly towards party leaders or top candidates (e.g., Walter 2013; Maier and Jansen, 2017), but rarely to the entire universe of individual party candidates (but see Ennser-Jedenastik et al. 2017). Yet, in a context of increasing personalization of politics and election campaigns in Europe (Adam \& Maier 2010) and the rise of social media that offer candidates with a new channel for selfpromotion (Karlsen 2011), candidates have increased incentives to run their own campaigns, independently from the party-especially in electoral systems that offer voters with the opportunity to express preferences for individual candidates (e.g., Makropoulos et al., 2021). Such personalized campaigns are generally studied with respect to their overall focus on the candidate rather than the party, the use of personal campaign means, or a candidate-centered campaign organization. Arguably, however, individualized campaigns are also reflected in campaign content, among others in a differing use of negative campaigning. Candidates who run personalized campaigns are probably less likely to go negative on their opponents, because in the spotlight there is less place to hide in case of backlash effects (Maier \& Nai, 2021). Thus, studying the campaign behavior of candidates becomes more pressing in a context of increasing personalization.

Second, most research remains focused on strategic dynamics, while the role of personal attributes of competing candidates is less studied. It is generally accepted that negative campaigning is a rational decision based on weighing costs (e.g., backlash effects stemming from the fact that the public at large broadly dislikes negative campaigning; see, e.g., Fridkin \& Kenney 2011) and benefits (a potential increase of the sender's "net favorability"; see, e.g., Benoit 2007, p. 36); the use of attacks and the factors that favor (or inhibit) it are usually considered against the backdrop of this theoretical framework (e.g., Lau \& Pomper 2004, p. 31; Walter \& Nai, 2015). However, it is easy to find examples where the attack behavior of candidates does not match the theoretical expectations. Probably the most prominent one is Donald Trump who, as an incumbent in the first 2020 presidential debate, "behaved like a bully" with "no strategy, just kill and eat". ${ }^{1}$ The question is, how we can explain

\footnotetext{
1 POLITICO, “Trumps' strategy is to turn the debates into a dumpster fire on steroids"”. Retrieved 20 August 2021 from https://www.politico.com/news/magazine/2020/09/30/trump-biden-debate-roundup423475
} 
attack behavior beyond "classic" rational choice considerations? We argue that personality traits are an important piece of the puzzle from the group of "non-strategic factors" that can explain candidates' campaign behavior. So far, little is known about how the personality of candidates affects their campaigning choices. Only a handful of studies have investigated how negativity is linked to candidates' personality (e.g., Maier \& Nai, 2021; Nai et al., 2019; Nai \& Maier, 2020), but most of these studies are focused on single countries. Third, and relatedly, comparative research into the drivers of attack behavior is largely missing. Moreover, the operationalization of central concepts usually differs and limits the possibility to compare the results from different studies. Therefore, there is a need for true comparative research using identical measurements in different countries.

Our article addresses these three shortcomings. We focus on the entire universe of parliamentary candidates, and comparatively investigate how their personality traits-the Big Five traits of extraversion, agreeableness, conscientiousness, neuroticism, and openness - impact the tone of their electoral campaigns. To do so, we introduce a previously rarely used data source for studying negative campaigning (for an exception see: Maier \& Nai, 2021): candidate surveys, gathered in the direct aftermath of the most recent national elections in three Western European countries - Germany, Switzerland, and Finland — based on a common questionnaire. Although all countries under investigation are "consensus democracies" (Lijphart 2012) and therefore quite similar in many respects, there are also important institutional differences. As compared to Germany, Switzerland and Finland have more fragmented party systems and highly competitive electoral systems at both the interparty and intra-party levels, providing candidates with incentives to run against fellow partisans and to organize personalized campaigns in order to cultivate a personal vote (e.g., von Schoultz 2018; Selb \& Lutz 2015). While these institutional features should lower the level of campaign negativity in Switzerland and Finland-on the one hand, the benefits of negative campaigns are more uncertain (and limited) when more candidates are competing for a seat (e.g., Walter 2014; Galasso et al. 2020), on the other hand negative campaigning against fellow partisans could hurt the party's overall vote share (Karvonen, 2010)—we do not expect such institutional aspects to alter the effects of personality traits on negative campaigning. Thus, the comparative perspective should mainly help us gain greater confidence in the robustness and generalizability of the theorized mechanisms.

\section{Candidates' personality and campaign negativity}

A common narrative suggests that the drivers of negative campaigning-that is, the reasons why candidates decide to criticize their rivals instead of showcasing a more positive campaign focusing on their own past deeds and future plans-find their roots in a strategic view of electoral competition. Negative campaigning might be effective to lower perceptions of the target, but is also profoundly disliked by the public at large (Fridkin \& Kenney 2011; Lipsitz et al. 2005). As such, it is a particularly risky strategy, that can easily backfire against the sponsor of the attacks and turn the public_or part of it, anyway_against them (Roese \& Sande 1993). 
With this in mind, strategic considerations and a risk and benefits calculation can be expected to prime in the decision to go negative or positive. For instance, research has shown that candidates tend to go negative when they have "nothing else to lose"that is, when they are behind in the polls and face the prospect of electoral defeat (Skaperdas \& Grofman 1995).

But politics is not only strategy. Even in an increasingly professionalized milieu, it seems unlikely that only tactical considerations matter. Some behavior is a result of non-strategical subjective considerations often bound to a candidate's personal profile. Recent research indicates that personality traits are a powerful driver of attitudes and behaviors, including campaigning choices of competing candidates (e.g., Scott \& Medeiros 2020; Vecchione \& Caprara 2009; Gerber et al. 2011). This makes sense since personality-a "multifaceted, enduring internal psychological structure" (Mondak et al. 2010, p.86) or, more simply, "who we are as individuals" (Mondak 2010 , p. 2) — has been shown to be relatively stable over the lifetime and most likely exogenous from political attitudes and ideological profile.

A very small body of research provides evidence that candidate's personality affects the decision to go negative (e.g., Maier \& Nai, 2021; Nai et al., 2019; Nai \& Maier, 2020). However, most evidence is based on expert surveys. In this article, we go beyond previous research, and test for the driving role of personality traits for negative campaigning in a comparative perspective using responses of those, who are responsible for attack behavior: the candidates themselves. In the next step, we will discuss the mechanisms behind the impact of personality traits on negative campaigning.

\section{Big Five and negative campaigning}

Among the multiple competing classifications of personality in the literature the Big Five Inventory (BFI) (John et al. 2008; Gerber et al. 2010) is one of the most authoritative. The BFI describes five personality traits: extraversion, agreeableness, conscientiousness, neuroticism, and openness. First, extraversion reflects a sociable, energetic, active, and bold character. In political leaders, extraversion has been associated with charismatic leadership (Bono \& Judge 2004), itself linked with greater success during turbulent times due to greater mobilization and persuasion of followers (De Hoogh et al. 2005). Next to sociability, extraversion is characterized by high boldness, social dominance, and disinhibition (e.g., Newman 1987)—all facets that can be logically expected to be associated with harsher campaigns. Politics is the realm of conflict by excellence, and social dominance seems a particularly adaptive trait in this sense. Furthermore, boldness and lack of inhibition could prevent highly extroverted candidates from identifying (or caring about) the potential risks associated with more negative campaigns. Although recent studies have failed to provide evidence for this link (Maier \& Nai, 2021; Nai, 2019), we nevertheless think that the theoretical arguments are convincing and thus expect higher negativity in candidates scoring high in extraversion (H1).

Second, research has demonstrated that high agreeableness-i.e., a trait ascribed to warm and sympathetic individuals-decreases the likelihood for candidates to 
be verbally aggressive (de Vries et al. 2013) and to attack their political opponents (e.g., Nai, 2019). Agreeable individuals tend to engage in pro-social activities and communal social interactions and display a marked preference for conflict avoidance (Jensen-Campbell et al. 2003). Populist politicians represent perhaps the most indicative example of these dynamics; expert surveys show that they score simultaneously quite low on agreeableness (e.g., Nai \& Martínez i Coma, 2019). Lower negativity is thus expected for candidates high in agreeableness $(\mathrm{H} 2)$.

Third, high conscientiousness is associated with professional success, achievement orientation (the tendency to be persistent in the pursuit of one's own goals), dependability, and a proclivity for organization and planning (Judge et al. 1999; Seibert and Kraimer 2001). Conscientious individuals show constraint in social interactions and have been shown to perform particularly well in challenging situations, where their predisposition for perseverance allows them to identify and overcome the hurdles they face (Hochwarter et al. 2000). In this sense, conscientiousness can act as the opposite of extraversion: where the former indicates prudence and constraint, the latter is often associated with impulsivity and energy. Recent studies on candidate campaign behavior were not able to show such a relationship (Maier \& Nai, 2021). Since the theoretical arguments are quite strong, we nonetheless expect that candidates high on conscientiousness should be less likely to go negative on their rivals (H3).

Fourth, we might also expect candidates scoring high on neuroticism (low emotional stability) to be more likely to go negative on their rivals ( $\mathrm{H} 4)$, although there is no corresponding empirical evidence for candidates yet, including using candidate survey data (Maier \& Nai, 2021). Neuroticism is often associated with edginess and anxiety, and neurotic individuals have been shown to report higher scores of impulsiveness and premeditated aggressiveness (Stanford et al., 2003). Furthermore, low emotional stability is associated with a negative image of the self and the others, depression, and low happiness (Hills \& Argyle 2001).

Expectations for the last remaining trait, openness, are less straightforward. High levels of openness are associated with "increased creativity, curiosity, imagination and nonconformity" (Mondak \& Halperin 2008, p. 342), whereas individuals lacking these characteristics tend to be closed-minded. Some evidence suggests that candidates scoring low on openness tend to use a more aggressive and fearful rhetoric (Maier \& Nai, 2021; Nai et al., 2019), but we fail to see a theoretical rationale linking the two in a straightforward way, as it is the case for the other four traits.

\section{Meta-traits and negative campaigning}

The five general personality traits are not independent conceptual and empirical constructs, and consistent evidence exists that identifies a smaller number of underlying meta-traits (e.g., Digman 1997; DeYoung 2006). The most widespread conceptualization identifies two meta-traits, the so-called "Huge Two" (Silvia et al. 2008; 2009): stability, first, reflects high scores on agreeableness and conscientiousness, and low scores on neuroticism; stability indicates a general tendency "to maintain stability and avoid disruption in emotional, social, and motivational domains" 
(DeYoung 2006, p. 1138). Plasticity, second, reflects high scores on extraversion and openness; plasticity can be seen as the tendency "to explore and engage flexibly with novelty, in both behavior and cognition" (DeYoung 2006, p. 1138).

Expectations for the two meta-traits come directly from the rationales associated with the main traits that compose them. First, as we expected lower negativity for candidates scoring high on agreeableness and conscientiousness and low on neuroticism, lower negativity is expected for candidates high in the meta-trait of stability (H5). Second, even if we do not have precise expectations for the effect of openness, the clear positive effect of extraversion on negativity that we anticipate is sufficient to posit that the meta-trait of plasticity is also positively associated with higher negativity (H6).

\section{Issue and character attacks}

Research has consistently highlighted that political attacks can have different foci (see, e.g., Benoit 2007, p. 44): On the one hand, criticism of the political opponent can deal with issues and policy positions. On the other hand, attacks can focus on the opponents' persona and character. Character attacks can often be stronger and uncompromising. Because of this, we might expect, first, agreeableness to have a stronger (negative) effect on the use of character attacks-that is, candidates scoring high on agreeableness should be comparatively even less likely to use character attacks than they are to use issue attacks. Available studies confirm this expectation. First, expert surveys have shown that low agreeableness is linked to character attacks, and that populist politicians, who are usually less agreeable than politicians from mainstream parties, rely frequently on character attacks and fear appeals (Nai \& Maier, 2020; Nai, 2021). Second, a study using data from a German candidate survey suggests that high agreeableness is linked to both lower character and lower issue attacks (Maier \& Nai, 2021). Hence, agreeable individuals shy away from conflict in general, and they should be expected to do so especially when it comes to particularly unpleasant circumstances (H7). Character attacks are more likely to backfire against their sponsor (Carraro \& Castelli 2010). We could thus expect second, character attacks to be more likely for candidates that tend to be impulsive and uninhibited - that is, scoring high in extraversion (H8). We do not have clear theoretically grounded expectations regarding the different usage of issue and character attacks for candidates scoring high on neuroticism, openness, and conscientiousness (and, thus, for the two underlying personality traits of stability and plasticity).

\section{Data and methods}

\section{Three candidate surveys}

We test our expectations based on data from three surveys, conducted among candidates having participated in the most recent national elections in Germany (2017), Switzerland (2019), and Finland (2019). 
The three surveys are part of the "Comparative Candidate Survey" and thus use a common questionnaire (CCS Module III), ensuring cross-country comparability (see Appendix for the original wording and translations of the questions capturing our main concepts, negative campaigning and personality traits). ${ }^{2}$ Data for the German election are part of the German Longitudinal Election Study (GLES). All candidates running for parties represented in the parliament ("Bundestag"), i.e., the Christian Democrats (CDU/CSU), the Social Democrats (SPD), the Green Party (Bündnis 90/ Die Grünen), and the Socialist Party (Die Linke), were asked to fill out a questionnaire (online or offline). In addition, the study includes also candidates from parties that did not belong to the Bundestag but had according to the polls a good chance to pass the electoral threshold, i.e., the Liberal Party (FDP) and the right-wing populist party AfD. From the initially 2,516 contacted candidates 803 participated in the study (representing a response rate of $31.9 \%$ ). 14.6\% of the participating candidates run for CDU/CSU, 18.7\% for the SPD, 20.7\% for Bündnis 90/Die Grünen, 16.3\% for Die Linke, $16.4 \%$ for the FDP and $13.3 \%$ for the AfD.

Data for the Swiss election were collected as part of the Swiss Election Study (Selects). The sample included all 4,736 candidates running for the National Council or the Council of States, regardless of their parties' representation in the parliament or their chances to win a seat. 2,158 candidates participated in the online/ paper survey, representing a response rate of $45.6 \%$. Three quarters of the participating candidates belong to one of the four governing parties (9.5\% ran for the Swiss People' Party, $10.1 \%$ for the Liberal Party, $16.9 \%$ for the Christian Democrats, and $14.9 \%$ for Social Democrats) or the two green parties (Green Party: 12.4\%, GreenLiberal Party: 11.4\%), whereas one quarter belongs to other party lists, covering the entire ideological spectrum.

The Finnish online/paper survey was carried out within the framework of the Intraparty Competition project. 770 candidates (out of a total of 2,468 nominated candidates) participated in the survey, representing a response rate of $31.2 \%$. Three quarters of the respondents belong to one of the parties elected to the current parliament: $9.2 \%$ belong to the Social Democrats (SDP), $8.9 \%$ to the Green League (VIHR), $8.9 \%$ to the Center Party (KESK), $8.9 \%$ to the Christian Democrats (KD), $8.6 \%$ to the Left Alliance (VAS), $7.8 \%$ to the National Coalition (KOK), $6.0 \%$ to the Blue Reform (SIN), 5.7\% to the Finns Party (PS) $4.9 \%$ to the Swedish People's Party (RKP) and $4.9 \%$ to Movement Now (LIIK).

We will run our analyses on the three datasets separately, to identify any potential diverging trends across the three countries, but also on the pooled dataset $(N=3,732)$. We use in all analyses a statistical weight already incorporated in the data. The weight, most important for our purposes, also adjusts the proportion of each party's candidates actually represented in the survey to the proportion of

\footnotetext{
2 To the best of our knowledge, these three countries are to date the only ones that have completed a candidate survey based on CCS III and that thus offer comparable data on negativity and candidates' personality traits. The German data and codebook are available through the GESIS archive (archive number 6814), the Swiss data and codebook are accessible from the FORS data archive FORSbase (dataset reference 1186), while the Finnish data is not yet publicly available. A comparative CCS III dataset will later be published in FORSbase.
} 

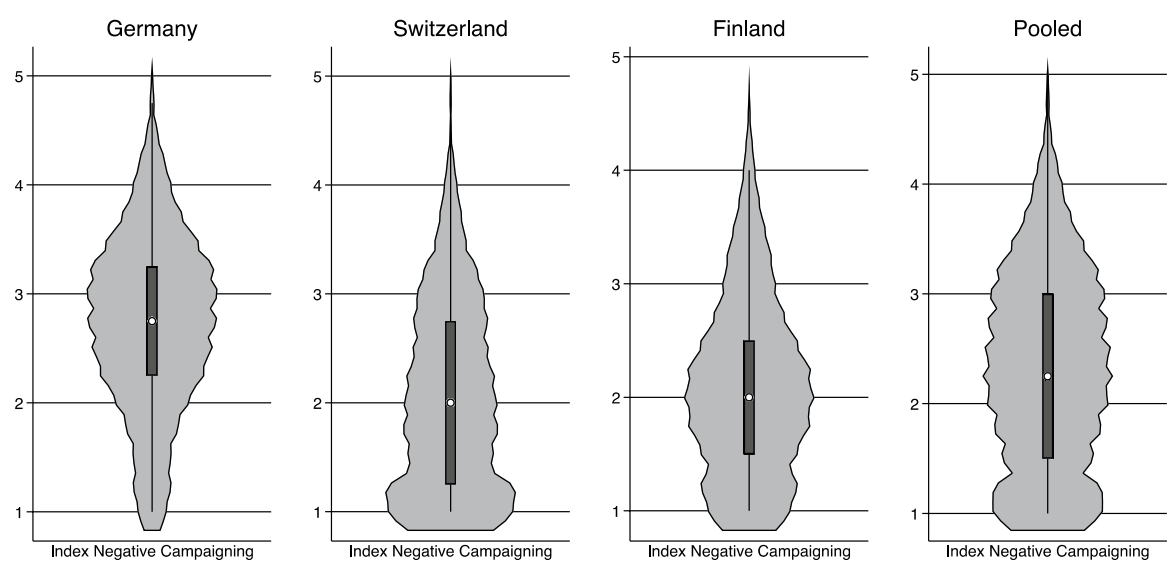

Fig. 1 Negative campaigning index by country

candidates nominated by the parties ("target population"). Thus, our data are representative of the candidates running for parliament (however, not for the candidates elected for parliament). For further information see the codebooks and study descriptions of the respective candidate surveys.

\section{Negative campaigning}

We measure the "tone" of candidates' campaigns via self-reported measures. Candidates were asked four questions with respect to their use of negative campaigning: "How strongly did you criticize each of the following aspects of other parties and candidates in your campaign? (1) Particular items on the platform of other parties, (2) Other parties' records during the term, (3) Issues specific to the personal campaign of other candidates, (4) Personal characteristics and circumstances of other candidates." 3 For each item a five-point scale from 1 ("not at all") to 5 ("very much") was provided. ${ }^{4}$ Hence, (low) high scores reflect a (low) high level of negative campaigning. All items are highly positively correlated. We created an additive index reflecting the general use of negative campaigning $(\alpha=0.78$ on the pooled dataset), ${ }^{5}$ that serves as the dependent variable for our analyses. This index ranges between 1 "not at all" and 5 "very strong" $(\mathrm{M}=2.34, \mathrm{SD}=0.92$ on the pooled

\footnotetext{
${ }_{3}$ The wording of these last two questions for Germany is slightly different, and specifically refer to attacks toward "candidates in other parties" (in Switzerland and Germany the wording is more general and refers to "other candidates"). Given that the introduction in the question frames the battery mostly in terms of attacks toward other parties, we do not believe this slight difference to be of any substantive consequence.

${ }^{4}$ The scale had to be reversed for Germany.

${ }^{5} \alpha_{\text {Germany }}=.71, \alpha_{\text {Switzerland }}=.79, \alpha_{\text {Finland }}=.77$.
} 

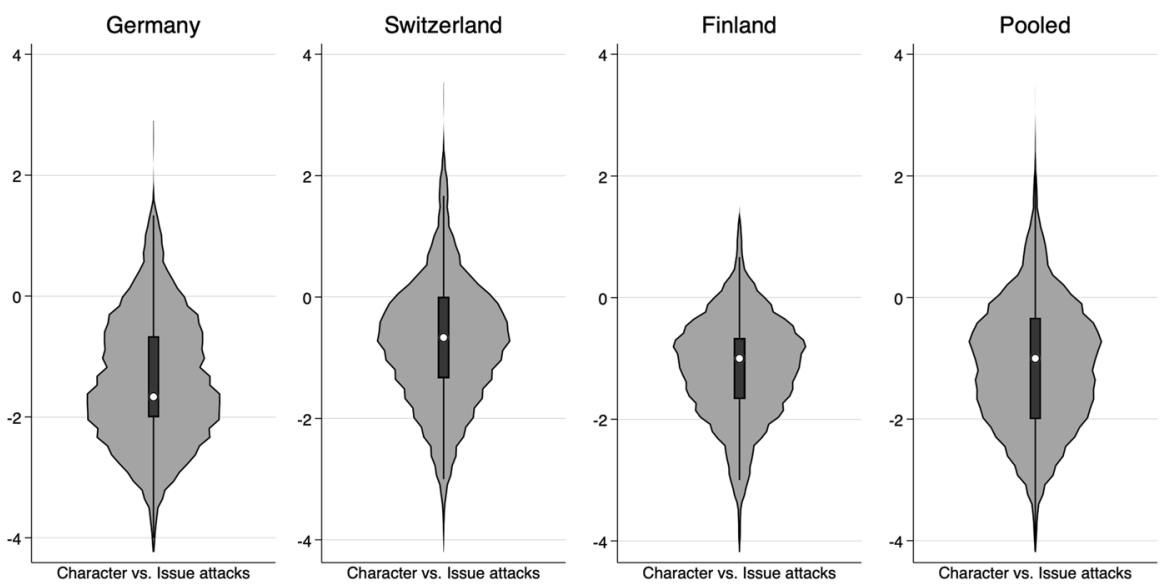

Fig. 2 Index Character vs. Issue attacks by country

dataset). The average level of negativity is rather low in Switzerland and Finland, and clearly higher in Germany (Fig. 1). ${ }^{6}$

The four items in the dataset related to candidates' self-reported use of negativity converge into a unitary index of negativity; a factor analysis (PCA) indicates that the items belong to a single higher-order dimension, explaining approximately $60 \%$ of the variance (pooled dataset; the same trend exists for each of the three countries separately). Nonetheless, from a conceptual standpoint, the four items reflect the distinction between attacks targeted toward issues (items 1, 2 and 3) and attacks toward the character of the opponent (item 4). We have thus computed two separate variables reflecting, respectively, the use of issue attacks ( $\alpha=0.78$, pooled dataset) ${ }^{7}$ and character attacks. Both variables vary between 1 ("not at all") and 5 ("very much"). To test $\mathrm{H} 7$ and H8, which expect candidates high in extraversion and low in agreeableness to privilege character rather than issue attacks, we have computed a new index that subtracts the index of issue attacks from the measure of character attacks; however, we have excluded candidates who indicated that they never attacked their opponents (i.e., having the score 1 on our index of general use of negative campaigning). This index reflects the understanding in the literature about the one-dimensional nature of the focus of attacks: after choosing to go negative, the candidates have to decide whether to attack the opponent on policy or on character (e.g., Brooks \& Geer, 2007; Hopmann et al., 2018). The variable varies theoretically between -4 and +4 ; high scores reflect a great use of character attacks and a low use of issue attacks, whereas low scores indicate the reverse. Candidates who went

\footnotetext{
${ }^{6} \alpha_{\text {Germany }}: M=2.74, \mathrm{SD}=.84 ; \alpha_{\text {Switzerland }}: M=2.07, \mathrm{SD}=.91 ; \alpha_{\text {Finland }}: M=2.11, \mathrm{SD}=.80$.

$7 \alpha_{\text {Germany }}=.71, \alpha_{\text {Switzerland }}=.77, \alpha_{\text {Finland }}=.78$.
} 
negative during their campaign tend to avoid character attacks and prefer to attack on issues $(\mathrm{M}=-1.12, \mathrm{SD}=1.03$ on the pooled dataset; Fig. 2$){ }^{8}$

Self-reports about the use of negative campaigning might suffer from validity issues. However, there are good reasons to assume that the candidates' motivation to downplay the level of negativity they have used in the campaign is less severe in the context of our study. More than other professions, political candidates-especially when they are running for office-have strong incentives to be sincere; honesty, sincerity, and integrity are perhaps the most important image traits that voters look for in competing candidates (Holian \& Prysby 2014). Given that the candidate datasets are anonymized, we cannot validate the reported levels of negative campaigning with external measures at the candidate level. We were however able, for German and Finnish candidates, to compare the average level of self-reported negativity at the party level with expert ratings of campaign tone for those same parties, coming from an independent expert survey about negative campaigning worldwide. Results indicate that the correlation between average self-evaluation of negativity per party and independent expert ratings of campaign tone is clearly positive and rather strong, $\mathrm{r}(11)=0.61, p=0.026$, supporting our assumption (see Fig. A1 in Online Appendix). Moreover, we are not interested in investigating the level of negativity across candidates, but rather the conditions under which different candidates report different levels of campaign tone. In this sense, a generalized underestimation of the actual levels of negativity - if occurring — should have no implications for the analysis of its drivers.

\section{Personality}

Measuring the personality of political figures and candidates is challenging. Three competing approaches exist, all coming with caveats. First, the personality of political figures can be deducted from their behavior or discourse (e.g., parliamentary speeches; Ramey et al. 2017). Currently it is however not yet clear whether this approach can yield consistent results across different contexts (e.g., different languages or communication situations), and of course the results are contingent on the availability of materials to be coded and - in comparative studies_-on the presence of similar materials across all cases under investigation. Second, recent research makes use of expert assessments (e.g., Lilienfeld et al. 2012; Nai \& Maier, 2018, 2019). The use of experts to measure political phenomena is not without risks, especially in terms of their ideological neutrality (e.g., Wright \& Tomlinson 2018; but see Nai \& Maier, 2019), but does not face limitations in terms of social desirability biases (as self-reports do), can theoretically be replicated in virtually all contexts, and circumvents the need of having at hand comparable secondary data to code across all cases. Nonetheless, the use of expert ratings is particularly indicated for large-scale comparative analyses of top candidates and less effective for large

\footnotetext{
${ }^{8}$ Germany: $\mathrm{M}=-1.38, \mathrm{SD}=1.05$; Switzerland: $\mathrm{M}=-.77, \mathrm{SD}=1.02$; Finland: $\mathrm{M}=-1.18, \mathrm{SD}=.86$. Country differences are significant $\left(F_{2,3009}=110.73, p<.001\right)$. A post-hoc Scheffé test shows that all countries differ significantly from each other at $p<.01$.
} 
samples of often unknown competing candidates in few contexts, such as in this article.

The third approach, which we adopt here, relies on self-reported measures to assess the personality of political elites (e.g., Dietrich et al. 2012; Joly et al. 2019; Schumacher \& Zettler 2019; Scott \& Medeiros 2020). This approach invites political figures (in our case, candidates) to complete questionnaires that include standardized batteries for the measurement of personality traits that are usually employed for the public at large. The Big Five personality traits have been assessed through a large number of different measurement instruments of varied lengths. Initially, extensive personality batteries, sometimes comprising hundreds of items, were used to provide an exhaustive measure of the different facets of each of the Big Five dimensions (for an overview, see John \& Srivastava 1999). More recently, ultrashort measures were developed to accommodate the strong time constraints of large, multi-topic surveys that are not mainly interested in personality traits as such, but rather in their consequences for various social or political outcomes. One such short scale is the BFI-10 (Rammstedt \& John 2007), which is used in our candidate surveys, as well as in well-known national and international population surveys in these countries (e.g., GESIS panel, Swiss Household Panel, ISSP 2005). ${ }^{9}$ The ten items measure core aspects of the Big five factors and represent each factor with one positively and one negatively keyed item.

To be sure, short measures of personality are not perfect. With only a few items per trait, they sacrifice validity for reliability (Spain et al. 2014; Bakker and Lelkes 2018) and cannot thus be expected to reproduce the full nuances of personality shades and facets. With this in mind, and to test for hypotheses H5 and H6, we have computed two variables that reflect the two underlying traits of plasticity (high extraversion and openness) and stability (high agreeableness and conscientious, low neuroticism), by simply averaging the scores on the relevant traits (reversed scores for neuroticism). Figure 3 illustrates the distribution of observations in the three countries (and the pooled dataset) on the five general traits and the two underlying factors of plasticity and stability. Table 1 presents zero-order correlations for the Big Five measures and our measures for negative campaigning.

Asking politicians about their personality traits is not without challenges. In particular, social desirability might influence politicians to not reveal their "true" personality. We, however, believe that the issue is not as problematic as one could imagine. Even though other candidate studies indicate that politicians ascribe themselves more positive traits, the observed bias does not appear to be overly strong, at least not stronger than in citizen samples (Schumacher \& Zettler 2019). In fact, some studies report that politicians score lower than ordinary citizens on some personality traits intuitively categorized as socially desirable (e.g., Best 2011). Moreover, it is not clear per se what qualities politicians themselves find desirable; they

\footnotetext{
9 The BFI-10 is similar to other established short measures of the Big Five personality traits, such as the ten-item personality inventory (TIPI), developed by Gosling and colleagues (Gosling et al. 2003). In contrast to TIPI, which introduce new trait adjectives, the BFI-10 is based on the original items of the Big Five Inventory.
} 


\section{Germany}



Switzerland

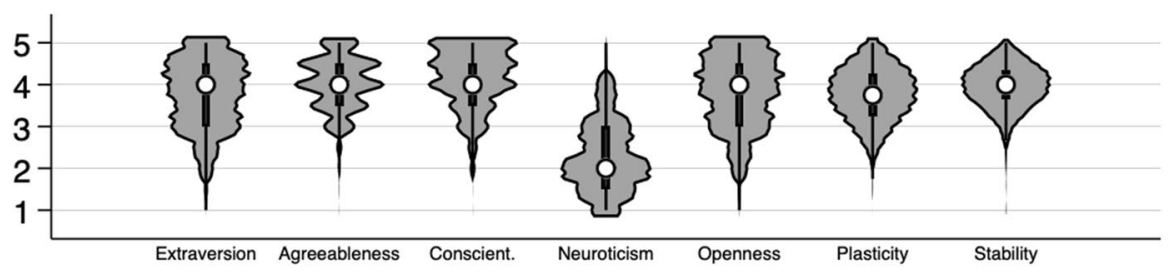

Finland



Pooled

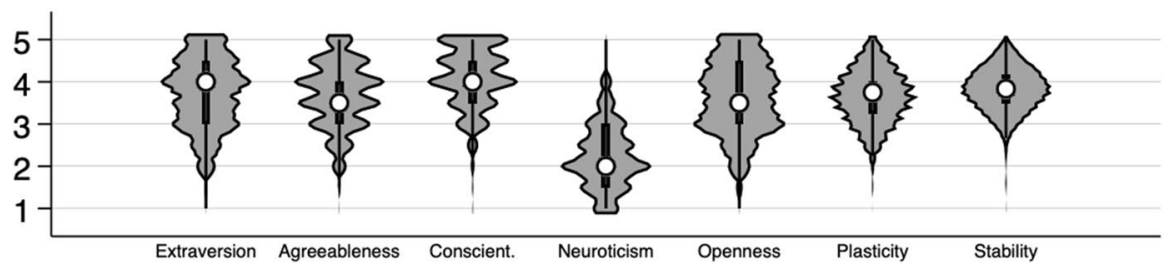

Fig. 3 Personality traits by country

may consider high self-esteem, tactical skill, and a certain ruthlessness to be prerequisites for being truly successful in the political arena (Schumacher \& Zettler 2019).

\section{Covariates}

All models are controlled by a series of covariates that act as "powerful alternatives" to explain the use of negative messages. These controls can be classified in four main categories. First, the political experience of candidates is measured via their incumbency status (i.e., whether they are already members of parliament at 
Table 1 Zero-order correlations (pooled data, three countries)

\begin{tabular}{|c|c|c|c|c|c|c|c|c|c|c|c|c|}
\hline & & & & & & $\begin{array}{l}\text { Nega- } \\
\text { tive } \\
\text { camp. } \\
\text { index }\end{array}$ & CVI & $\mathrm{E}$ & A & $\mathrm{N}$ & $\mathrm{O}$ & PL \\
\hline $\begin{array}{l}\text { Character } \\
\text { vs }\end{array}$ & $\mathrm{R}$ & & & & & -0.23 & & & & & & \\
\hline \multirow{2}{*}{$\begin{array}{l}\text { issue } \\
\text { attacks } \\
\text { (CVI) }\end{array}$} & $\mathrm{P}$ & & & & & 0.000 & & & & & & \\
\hline & $\mathrm{N}$ & & & & & 3012 & & & & & & \\
\hline \multirow{3}{*}{$\begin{array}{l}\text { Extraver- } \\
\quad \text { sion (E) }\end{array}$} & $\mathrm{r}$ & -0.04 & 0.05 & & & & & & & & & \\
\hline & $\mathrm{p}$ & 0.018 & 0.004 & & & & & & & & & \\
\hline & $\mathrm{n}$ & 3533 & 2925 & & & & & & & & & \\
\hline \multirow{3}{*}{$\begin{array}{l}\text { Agreeable- } \\
\text { ness } \\
\text { (A) }\end{array}$} & $\mathrm{r}$ & -0.32 & 0.13 & 0.18 & & & & & & & & \\
\hline & $\mathrm{p}$ & 0.000 & 0.000 & 0.000 & & & & & & & & \\
\hline & $\mathrm{n}$ & 3535 & 2928 & 3593 & & & & & & & & \\
\hline \multirow{3}{*}{$\begin{array}{l}\text { Conscien- } \\
\text { tious- } \\
\text { ness } \\
\text { (C) }\end{array}$} & $\mathrm{r}$ & -0.10 & 0.03 & 0.17 & 0.19 & & & & & & & \\
\hline & $\mathrm{p}$ & 0.000 & 0.075 & 0.000 & 0.000 & & & & & & & \\
\hline & $\mathrm{n}$ & 3534 & 2927 & 3590 & 3594 & & & & & & & \\
\hline \multirow{3}{*}{$\begin{array}{l}\text { Neu- } \\
\text { roticism } \\
(\mathrm{N})\end{array}$} & $\mathrm{r}$ & 0.05 & 0.03 & -0.22 & -0.21 & -0.23 & & & & & & \\
\hline & $\mathrm{p}$ & 0.003 & 0.168 & 0.000 & 0.000 & 0.000 & & & & & & \\
\hline & $\mathrm{n}$ & 3532 & 2926 & 3588 & 3591 & 3590 & & & & & & \\
\hline \multirow{3}{*}{$\begin{array}{l}\text { Openness } \\
\text { (O) }\end{array}$} & $\mathrm{r}$ & 0.04 & -0.02 & 0.10 & 0.01 & 0.08 & -0.07 & & & & & \\
\hline & $\mathrm{p}$ & 0.037 & 0.391 & 0.000 & 0.542 & 0.000 & 0.000 & & & & & \\
\hline & $\mathrm{n}$ & 3532 & 2925 & 3586 & 3590 & 3590 & 3589 & & & & & \\
\hline \multirow{3}{*}{$\begin{array}{l}\text { Plasticity } \\
\text { (PL) }\end{array}$} & $\mathrm{r}$ & -0.00 & 0.03 & 0.73 & 0.13 & 0.17 & -0.19 & 0.75 & & & & \\
\hline & $\mathrm{p}$ & 0.866 & 0.167 & 0.000 & 0.000 & 0.000 & 0.000 & 0.000 & & & & \\
\hline & $\mathrm{n}$ & 3525 & 2919 & 3586 & 3585 & 3584 & 3584 & 3586 & & & & \\
\hline \multirow[t]{3}{*}{ Stability } & $\mathrm{r}$ & -0.23 & 0.07 & 0.28 & 0.68 & 0.68 & -0.71 & 0.08 & 0.24 & & & \\
\hline & $\mathrm{p}$ & 0.000 & 0.000 & 0.000 & 0.000 & 0.000 & 0.000 & 0.000 & 0.000 & & & \\
\hline & $\mathrm{n}$ & 3527 & 2922 & 3586 & 3589 & 3589 & 3589 & 3586 & 3582 & & & \\
\hline
\end{tabular}

the time of the election), their membership to a governing party, and their previous experience in running campaigns (count variable, ranging from 0 to 4 ). Second, their ideology is measured via their self-reported left-right position (11-point scale from 1 "left" to 11 "right"), extremism (6-point scale from 0 "moderate" to 5 "extreme", obtained by folding the left-right variable on itself), and their ideological distance with their party (11-point scale from 0 "no difference" to 10 "maximal difference"). Third, we measure dynamics of the race via a variable that captures 
whether candidates are running a professional campaign (indicated by the presence of a campaign manager; binary variable), the size of their campaign team (number of persons), the candidate's perceived closeness of the race (3-point scale from 0 "not close at all" to 2 "very close"), ${ }^{10}$ and their self-assessed campaign goal (that is, whether they are campaigning for themselves or for their party; 11-point scale from 1 "attention for self" to 11 "attention for party"). Finally, we control for the candidates' demographic profile in terms of gender, age in years, and migration background (binary variable).

\section{Results}

\section{Personality and negativity}

Table 2 presents the results of a series of linear regressions that estimate the candidates' campaign tone by their personality profile, plus a series of covariates. The first three models are run separately for the three countries, whereas M4 is run on the pooled data.

Looking first at the effect of covariates, Table 2 confirms some familiar trends from the existing literature. More positive campaigns are run by candidates from governing parties (except in Switzerland, but this is likely due to the collegial nature of the Swiss federal executive), in line with several studies showing that incumbents are less likely to go negative (e.g., Lau \& Pomper 2004; Benoit 2007). Across all countries, higher negativity is also reported for more ideologically extreme candidates (Nai, 2020). Political extremism is associated, almost by definition, with a more uncompromising political style, and it is thus logical to expect negative campaigns to be "in character" for more extreme candidates. Higher negativity exists also when the race is perceived as close (Fowler et al. 2016), and for younger candidates, perhaps because adopting a less conservative campaigning style. The effect of gender is less clear, reflecting mixed findings in earlier studies (for a summary, see e.g., Maier, 2015): Female candidates are associated with less negative campaigns in Germany and Finland, but with more negative campaigns in Switzerland-the only country out of the three where more women than men competed in the election under investigation. Finally, candidates in Switzerland and Finland tend, in comparison with their German counterparts, to run more positive campaigns. If uncovering country differences is not the goal here, this trend makes sense in light of Lijphart's (2012) classification of Switzerland and Finland as scoring particularly highand substantively higher than Germany-on the "executive-parties" axis of his two-dimensional conceptual map of democracy (2012, ap. 244). The "executiveparties" dimension, broadly speaking, reflects greater party fragmentation, lower

\footnotetext{
10 Our measurement captures perceived competitiveness (across the board), regardless of the reasons why the race is competitive or not. The perceived competitiveness does, of course, not necessarily reflect the real closeness of the race. However, we claim that perceptions are more likely to affect behavior than real situations.
} 
electoral disproportionality and interest groups' pluralism, and weaker executive dominance-all factors that are conceptually related with a "gentler, kinder" democratic exercise as a whole.

Beyond providing a baseline model on top of which we will identify the effects of candidates' personality traits, these results-because confirming important trends in the literature-provide an important indirect validation of our measures of campaign negativity. Self-reported measures of negativity seem to follow predicted patterns when it comes to the effect of personal and structural factors.

Turning to the effect of personality traits, candidates scoring higher in extraversion are marginally more likely to go negative on their rivals. The effect is not particularly strong but significant (except for Finland), but is in line with our expectations (H1). Much stronger, and confirming H2, is the negative effect of agreeableness; the effect exists throughout (for all three countries and the pooled data), and clearly indicates that candidates scoring high on agreeableness are, ceteris paribus, less likely to attack. The effect is relatively substantial: compared with candidates who score the lowest on this trait, highly agreeable candidates score 0.8 points (out of 5) less on self-reported negativity. This effect is perfectly in line with recent research showing that "harsher" candidates-populists, who tend to showcase a political style intended to breach social norms of civility and cooperation (Moffitt 2016) and who score quite low on agreeableness-are more likely to go negative in their campaigns (e.g., Nai, 2021). We then find partial confirmation of $\mathrm{H} 3$, according to which candidates scoring high on conscientiousness are associated with lower negativity; the effect is however rather small and only significant in the pooled dataset. Disconfirming H4, but in line with a German study (Maier \& Nai, 2021), we find no significant effect of neuroticism on self-reported negativity; the same goes for openness.

\section{Meta-traits}

Table 3 replicates the same models but estimates the direct effect of the metatraits of stability and plasticity instead of the Big Five separately. Results generally confirm our expectations. Plasticity (the average score of extraversion and openness) is significantly associated with greater negativity, especially in Germany and Switzerland; even if the effect is not significant in Finland and more marginal in the pooled dataset, the general trend confirms H5. The effects are more clear-cut for the second meta-trait, stability (the average score of agreeableness, conscientiousness, and reversed neuroticism). Stability is significantly and rather strongly associated with lower negativity, in line with H6. Figure 4 substantiates the marginal effects of plasticity and stability on self-reported campaign negativity, when all other variables in the models are kept constant at their mean (pooled data). 
Table 2 Negative campaigning index and candidate personality traits

\begin{tabular}{|c|c|c|c|c|c|c|c|c|c|c|c|c|}
\hline & \multirow{2}{*}{\multicolumn{3}{|c|}{$\frac{\text { Germany }}{\text { M1 }}$}} & \multirow{2}{*}{\multicolumn{3}{|c|}{$\frac{\text { Switzerland }}{\text { M2 }}$}} & \multicolumn{3}{|l|}{ Finland } & \multicolumn{3}{|l|}{ Pooled } \\
\hline & & & & & & & \multicolumn{3}{|l|}{ M3 } & \multicolumn{3}{|l|}{ M4 } \\
\hline & Coef & $\mathrm{Se}$ & Sig & Coef & $\mathrm{Se}$ & Sig & Coef & $\mathrm{Se}$ & Sig & Coef & $\mathrm{Se}$ & Sig \\
\hline Incumbency & 0.13 & $(0.10)$ & & 0.17 & $(0.12)$ & & 0.09 & $(0.15)$ & & 0.04 & $(0.06)$ & \\
\hline $\begin{array}{l}\text { Party member } \\
\text { of gvt }\end{array}$ & -0.56 & $(0.07)$ & $* * *$ & 0.07 & $(0.04)$ & & -0.28 & $(0.07)$ & $* * *$ & -0.24 & $(0.03)$ & $* * *$ \\
\hline Experience & -0.04 & $(0.05)$ & & -0.05 & $(0.03)$ & $*$ & 0.10 & $(0.04)$ & & -0.02 & $(0.02)$ & \\
\hline Left-right & -0.00 & $(0.01)$ & & -0.00 & $(0.01)$ & & -0.01 & $(0.01)$ & & 0.01 & $(0.01)$ & \\
\hline Extremism & 0.09 & $(0.02)$ & $* * *$ & 0.11 & $(0.01)$ & $* * *$ & 0.09 & $(0.02)$ & $* * *$ & 0.11 & $(0.01)$ & $* * *$ \\
\hline $\begin{array}{l}\text { Distance from } \\
\text { party }\end{array}$ & -0.00 & $(0.03)$ & & -0.01 & $(0.02)$ & & -0.03 & $(0.02)$ & & -0.02 & $(0.01)$ & \\
\hline $\begin{array}{c}\text { Professional } \\
\text { campaign }\end{array}$ & -0.16 & $(0.13)$ & & 0.04 & $(0.07)$ & & -0.05 & $(0.15)$ & & -0.04 & $(0.06)$ & \\
\hline $\begin{array}{l}\text { Size of cam- } \\
\text { paign team }\end{array}$ & -0.00 & $(0.00)$ & & -0.00 & $(0.00)$ & & -0.00 & $(0.00)$ & & -0.00 & $(0.00)$ & \\
\hline $\begin{array}{l}\text { Perceived close- } \\
\text { ness of race }\end{array}$ & 0.12 & $(0.05)$ & $*$ & 0.03 & $(0.03)$ & & 0.06 & $(0.04)$ & & 0.07 & $(0.02)$ & $* *$ \\
\hline $\begin{array}{l}\text { Campaign for } \\
\text { party not self }\end{array}$ & 0.01 & $(0.01)$ & & 0.00 & $(0.01)$ & & -0.01 & $(0.01)$ & & 0.00 & $(0.01)$ & \\
\hline Female & -0.16 & $(0.07)$ & $*$ & 0.26 & $(0.04)$ & $* * *$ & -0.37 & $(0.06)$ & $* * *$ & -0.03 & $(0.03)$ & \\
\hline Age & -0.00 & $(0.00)$ & $\dot{\dagger}$ & -0.01 & $(0.00)$ & $* * *$ & -0.00 & $(0.00)$ & & -0.01 & $(0.00)$ & $* * *$ \\
\hline $\begin{array}{l}\text { Migration back- } \\
\text { ground }\end{array}$ & 0.00 & $(0.15)$ & & 0.10 & $(0.07)$ & & -0.08 & $(0.17)$ & & 0.04 & $(0.06)$ & \\
\hline Switzerland ${ }^{\mathrm{a}}$ & & & & & & & & & & -0.48 & $(0.04)$ & $* * *$ \\
\hline Finland $^{\mathrm{a}}$ & & & & & & & & & & -0.54 & $(0.05)$ & $* * *$ \\
\hline Extraversion & 0.07 & $(0.04)$ & $\dagger$ & 0.06 & $(0.02)$ & $*$ & 0.03 & $(0.03)$ & & 0.03 & $(0.02)$ & $\dagger$ \\
\hline Agreeableness & -0.22 & $(0.04)$ & $* * *$ & -0.14 & $(0.03)$ & $* * *$ & -0.19 & $(0.05)$ & $* * *$ & -0.21 & $(0.02)$ & $* * *$ \\
\hline $\begin{array}{l}\text { Conscientious- } \\
\text { ness }\end{array}$ & -0.02 & $(0.04)$ & & -0.03 & $(0.03)$ & & -0.00 & $(0.04)$ & & -0.04 & $(0.02)$ & $*$ \\
\hline Neuroticism & -0.01 & $(0.04)$ & & 0.03 & $(0.02)$ & & 0.04 & $(0.04)$ & & -0.02 & $(0.02)$ & \\
\hline Openness & 0.04 & $(0.04)$ & & 0.02 & $(0.02)$ & & -0.04 & $(0.04)$ & & 0.02 & $(0.02)$ & \\
\hline Intercept & 3.29 & $(0.37)$ & $* * *$ & 2.36 & $(0.24)$ & $* * *$ & 2.98 & $(0.31)$ & $* * *$ & 3.49 & $(0.16)$ & $* * *$ \\
\hline $\mathrm{N}$ & 682 & & & 1,932 & & & 684 & & & 3,298 & & \\
\hline $\mathrm{R} 2$ & 0.18 & & & 0.12 & & & 0.18 & & & 0.21 & & \\
\hline $\begin{array}{r}\text { Minimum R2 } \\
\text { personality }\end{array}$ & $0.04 * * *$ & & & $0.02 * * *$ & & & $0.03 * *$ & & & $0.02 * * *$ & & \\
\hline
\end{tabular}

All models are linear regressions. The dependent variable (negative campaigning) is an additive index that varies between 1 'very low' and 5 'very high.' All models weighted by party strength

${ }^{\text {a}}$ Reference category is Germany

$* * * p<0.001, * * p<0.01,{ }^{*} p<0.05,{ }^{\dagger} p<0.1$

\section{Issue and character attacks}

Finally, Table 4 estimates the differential use of character and issue attacks by the candidates in the three countries (and the pooled dataset). The dependent variable in 
Table 3 Negative campaigning index and candidate personality traits (meta-traits)

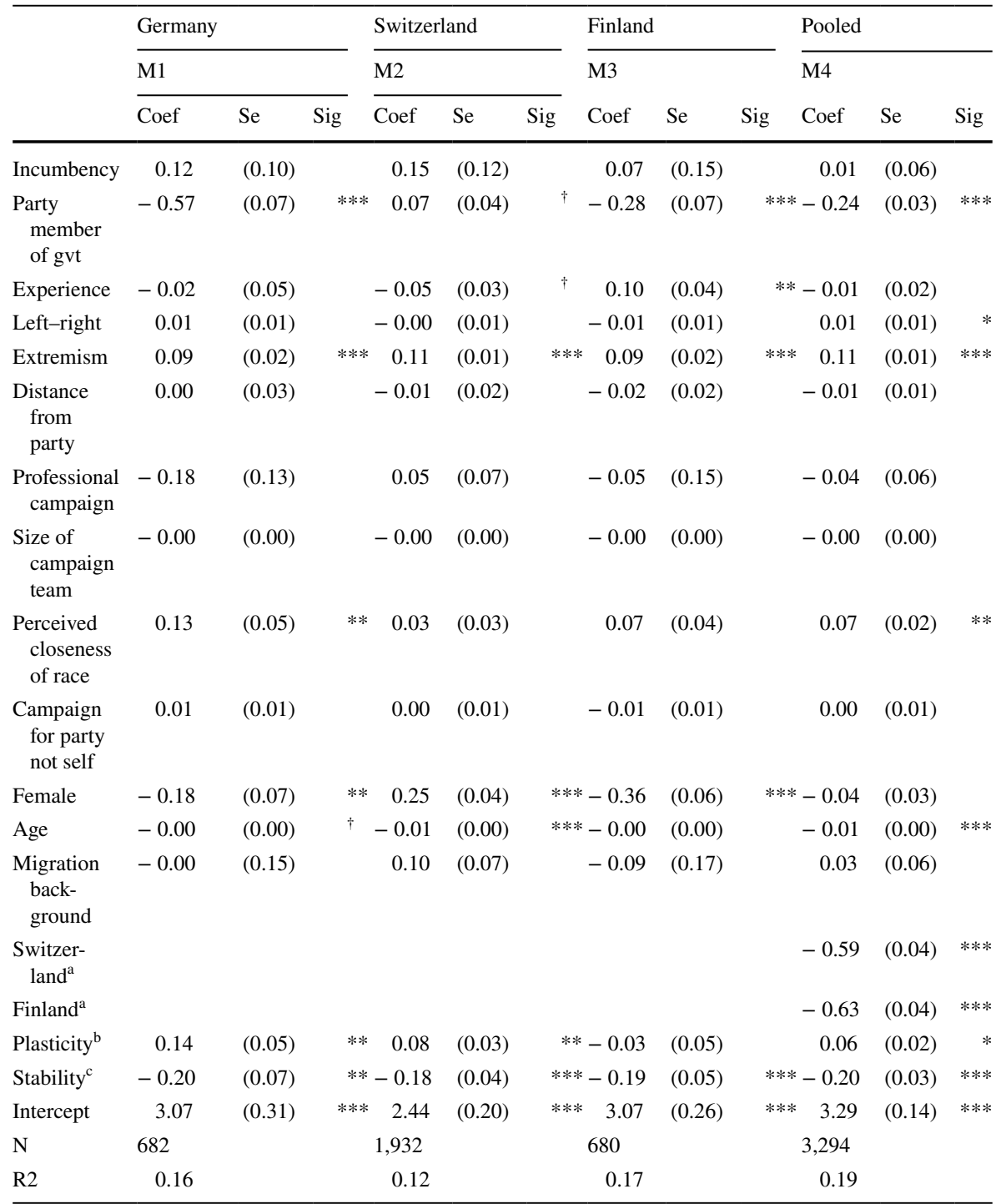

All models are linear regressions. The dependent variable (negative campaigning) is an additive index that varies between 1 'very low' and 5 'very high.' All models weighted by party strength

${ }^{a}$ Reference category is Germany

${ }^{\mathrm{b}}$ Extraversion, openness

${ }^{\mathrm{c}}$ Agreeableness, conscientiousness, neuroticism (reversed)

$* * * p<0.001, * * p<0.01, * p<0.05,{ }^{\dagger} p<0.1$

all models takes high scores when candidates made a high use of character attacks and low use of issue attacks, and vice-versa for low scores. 
Negative campaigning index
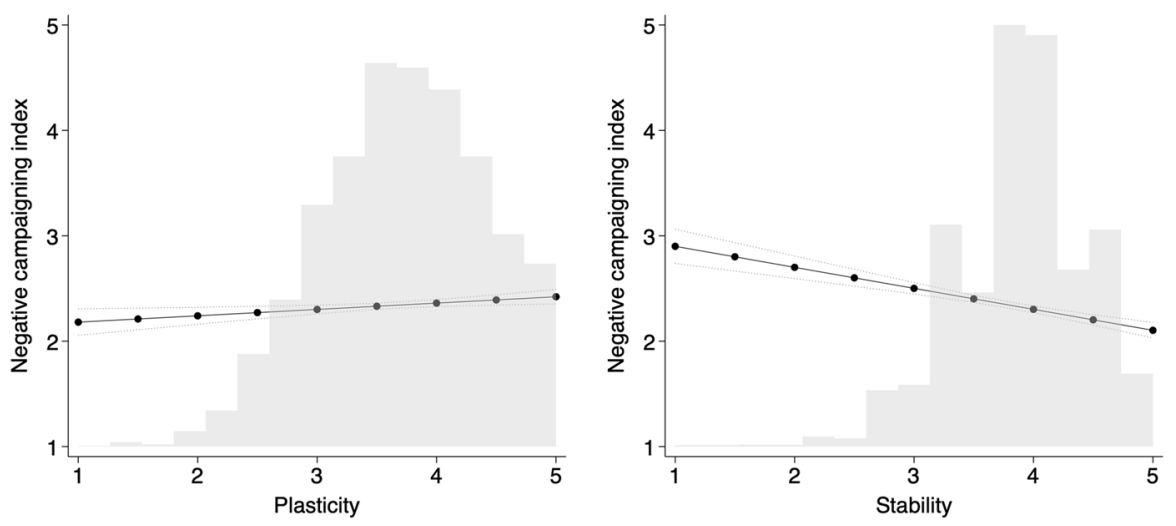

Fig. 4 Negative campaigning and second-order candidate personality traits (pooled data). Note: Pooled data. Marginal effects with $95 \%$ confidence intervals, based on coefficients in Table 3 (M4). All other variables fixed at their mean value

Compared to the general use of negative campaigning, the candidates' choice for character or issue attacks is much more difficult to explain. This might be an indication that, the decision on the actual focus of an attack is much more spontaneous and context-dependent than the general decision to go negative (or not). Looking at our covariates, we find the most coherent effects for ideology. Conservative and ideologically moderate candidates are significantly more likely to attack on character. This is also true for older candidates. The observed significant effects for incumbents, members of a governing party, and for gender are less clear-cut; they occur only in some countries and sometimes point in different directions.

With respect to personality traits, we expected candidates high in extraversion to prefer character over issue attacks (H7), and the reverse for candidates high in agreeableness (H8). Extraversion seems indeed associated with higher scores on the dependent variable, indicating a preference for character over issue attacks, but the effect is only significant in the pooled data set, thus only partially supporting $\mathrm{H}$. Agreeableness does not explain the predominant focus of attacks. Hence, H8 has to be rejected. Although we did not have any expectations regarding the effect of neuroticism, openness, and conscientiousness, it turns out that character attacks are preferred over issue attacks by candidates scoring high on neuroticism (except in Switzerland), while candidates high in conscientiousness tend to prefer issue attacks over character attacks (but only in Finland). Table 5 replicates the same analyses, but estimates the effect of the two meta-traits. Neither stability nor plasticity have any effect on the tradeoff between issue and character attacks in the three countries. In a nutshell, personality traits do not contribute much to our understanding of what factors lead candidates to attack the policy stands rather than the character of their opponents. 


\section{Discussion and conclusion}

Why do candidates go after their rivals in election campaigns? We claim that above and beyond the usual suspects - the candidates' social and political profile and competitive standings, and the nature of the electoral race-the personality profile of candidates can account for their decision to attack political opponents. Data from candidate surveys in Germany, Switzerland, and Finland provide support for this general expectation. More specifically, we find that negative campaigning is associated with low agreeableness and (marginally) with high extraversion and low conscientiousness. Higher negativity is also associated with lower levels on the meta-trait of stability. We also find marginal evidence that agreeableness (and, again, stability) are associated with a preference for issue over character attacks. All in all, kinder and more stable candidates tend to go negative less and, when they do, they tend to stay away from character-based attacks and somehow focus on issues.

Our study is not without limitations. First, the use of self-reports for the two central variables - negativity and personality - is suboptimal, as both could suffer from validity issues. As voters usually report that they do not like attacks (e.g., Fridkin and Kenney 2011) candidates might have a motivation to downplay the level of negativity they have used in the campaign. In other terms, due to social desirability it is not impossible that the self-reported level of negative campaigning in our data is lower than the "actual" negativity of their campaigns. Unfortunately, because the candidate datasets are anonymized, we have no direct way to cross-check the reported levels with external independent measures coming from, e.g., a content analysis of their campaign speeches. However, the comparison with experts' rating of parties' campaign negativity in Germany and Finland demonstrates that the candidates' self-reports used in this article are at least not "off the mark". A similar point can be made for self-reported measures of personality, and a question could be raised as to whether politicians are honest when answering personality batteries in questionnaires. Because the need to appear under a favorable light in the eye of the voter is part of their vocation, "politicians may be motivated to present themselves as having socially more desirable ('better') trait levels than they really have" (Schumacher \& Zettler 2019, p.176). Finally, and more seriously, it is possible that candidates with a given personality are more willing to report campaign negativity than others, or that different personalities perceive negativity differently. All of these problems could blur the relationship between personality traits and negative campaigning. Hence, further research triangulating objective external measures of campaign negativity with candidate perceptions is encouraged to shed light on these issues.

Second, our campaign negativity measure is not perfect, as it likely captures the strength of attacks rather than their frequency. Although the strong correlations with experts' assessment of German and Finnish parties' campaign negativity suggest that the candidates have interpreted the questions in terms of the frequency of their attacks, we agree with other scholars who have pointed out that the measurement of negative campaigning in campaign communication is often inconsistent in the literature (e.g., Lipsitz \& Geer, 2017; Haselmayer, 2019). 
Table 4 Character vs. issue attacks and candidate personality traits

\begin{tabular}{|c|c|c|c|c|c|c|c|c|c|c|c|c|}
\hline & \multirow{2}{*}{\multicolumn{3}{|c|}{$\frac{\text { Germany }}{\text { M1 }}$}} & \multirow{2}{*}{\multicolumn{3}{|c|}{$\frac{\text { Switzerland }}{\text { M2 }}$}} & \multicolumn{3}{|l|}{ Finland } & \multicolumn{3}{|l|}{ Pooled } \\
\hline & & & & & & & M3 & & & M4 & & \\
\hline & Coef & $\mathrm{Se}$ & Sig & Coef & $\mathrm{Se}$ & Sig & Coef & $\mathrm{Se}$ & Sig & Coef & $\mathrm{Se}$ & Sig \\
\hline Incumbency & -0.16 & $(0.14)$ & & -0.30 & $(0.16)$ & $\dagger$ & -0.28 & $(0.18)$ & & -0.12 & $(0.08)$ & \\
\hline $\begin{array}{l}\text { Party member } \\
\text { of gvt }\end{array}$ & 0.37 & $(0.10)$ & $* * *$ & 0.02 & $(0.06)$ & & 0.02 & $(0.09)$ & & 0.21 & $(0.04)$ & $* * *$ \\
\hline Experience & -0.07 & $(0.06)$ & & -0.00 & $(0.04)$ & & -0.07 & $(0.04)$ & & -0.04 & $(0.03)$ & \\
\hline Left-right & 0.00 & $(0.02)$ & & 0.05 & $(0.01)$ & $* * *$ & $=0.03$ & $(0.01)$ & $*$ & 0.02 & $(0.01)$ & $*$ \\
\hline Extremism & -0.07 & $(0.03)$ & $*$ & -0.04 & $(0.02)$ & $*$ & -0.10 & $(0.02)$ & $* * *$ & -0.07 & $(0.01)$ & $* * *$ \\
\hline $\begin{array}{l}\text { Distance from } \\
\text { party }\end{array}$ & 0.07 & $(0.04)$ & $\dagger$ & 0.01 & $(0.03)$ & & -0.03 & $(0.03)$ & & 0.02 & $(0.02)$ & \\
\hline $\begin{array}{c}\text { Professional } \\
\text { campaign }\end{array}$ & -0.11 & $(0.18)$ & & 0.02 & $(0.09)$ & & 0.14 & $(0.19)$ & & -0.02 & $(0.08)$ & \\
\hline $\begin{array}{l}\text { Size of cam- } \\
\text { paign team }\end{array}$ & -0.00 & $(0.00)$ & & 0.00 & $(0.00)$ & & -0.00 & $(0.00)$ & & -0.00 & $(0.00)$ & \\
\hline $\begin{array}{l}\text { Perceived } \\
\text { closeness of } \\
\text { race }\end{array}$ & -0.04 & $(0.06)$ & & 0.06 & $(0.05)$ & & 0.00 & $(0.05)$ & & 0.00 & $(0.03)$ & \\
\hline $\begin{array}{l}\text { Campaign for } \\
\text { party not self }\end{array}$ & -0.04 & $(0.01)$ & $* *$ & -0.01 & $(0.01)$ & & -0.00 & $(0.01)$ & & -0.02 & $(0.04)$ & \\
\hline Female & 0.05 & $(0.10)$ & & -0.25 & $(0.06)$ & $* * *$ & $=0.19$ & $(0.07)$ & & -0.02 & $(0.04)$ & \\
\hline Age & 0.01 & $(0.00)$ & $*$ & 0.00 & $(0.00)$ & $\dagger$ & 0.01 & $(0.00)$ & $*$ & 0.01 & $(0.00)$ & $* * *$ \\
\hline $\begin{array}{l}\text { Migration } \\
\text { background }\end{array}$ & 0.01 & $(0.20)$ & & 0.06 & $(0.04)$ & & 0.04 & $(0.23)$ & & 0.03 & $(0.08)$ & \\
\hline Switzerland $^{\mathrm{a}}$ & & & & & & & & & & 0.62 & $(0.05)$ & $* * *$ \\
\hline Finland $^{\mathrm{a}}$ & & & & & & & & & & 0.21 & $(0.06)$ & $* * *$ \\
\hline Extraversion & 0.07 & $(0.05)$ & & -0.01 & $(0.03)$ & & -0.00 & $(0.04)$ & & 0.04 & $(0.02)$ & $\dagger$ \\
\hline Agreeableness & 0.02 & $(0.06)$ & & -0.03 & $(0.04)$ & & 0.00 & $(0.06)$ & & 0.02 & $(0.03)$ & \\
\hline $\begin{array}{l}\text { Conscientious- } \\
\text { ness }\end{array}$ & 0.00 & $(0.06)$ & & 0.06 & $(0.04)$ & & -0.09 & $(0.05)$ & $\dagger$ & 0.00 & $(0.03)$ & \\
\hline Neuroticism & 0.11 & $(0.06)$ & $\dagger$ & -0.01 & $(0.03)$ & & -0.08 & $(0.05)$ & $\dagger$ & 0.04 & $(0.02)$ & $\dagger$ \\
\hline Openness & -0.07 & $(0.05)$ & & -0.02 & $(0.03)$ & & 0.07 & $(0.05)$ & & -0.03 & $(0.02)$ & \\
\hline Intercept & -1.80 & $(0.50)$ & $* * *$ & -0.90 & $(0.32)$ & $* *$ & -1.13 & $(0.39)$ & $* * *$ & -1.71 & $(0.21)$ & $* * *$ \\
\hline $\mathrm{N}$ & 653 & & & 1,508 & & & 578 & & & 2,739 & & \\
\hline $\mathrm{R} 2$ & 0.09 & & & 0.05 & & & 0.10 & & & 0.11 & & \\
\hline
\end{tabular}

All models are linear regressions. The dependent variable measures the use of character attacks instead of issue attacks and varies theoretically between -4 'high issue attacks and low character attacks' and +4 'high character attacks and low issue attacks.' All models weighted by party strength

${ }^{\text {a }}$ Reference category is Germany

$* * * p<0.001, * * p<0.01, * p<0.05,{ }^{\dagger} p<0.1$

Third, our study, due to the data used, is unable to say anything about whom the target of candidates' attacks might be. Who, exactly were candidates targeting when going negative? Yet, research has shown that the characteristics and the behavior of 
Table 5 Character vs. Issue attacks and candidate personality traits (meta-traits)

\begin{tabular}{|c|c|c|c|c|c|c|c|c|c|c|c|c|}
\hline & \multicolumn{3}{|c|}{ Germany } & \multicolumn{3}{|c|}{ Switzerland } & \multicolumn{3}{|l|}{ Finland } & \multicolumn{3}{|l|}{ Pooled } \\
\hline & \multicolumn{3}{|l|}{ M1 } & \multicolumn{3}{|l|}{ M2 } & \multicolumn{3}{|l|}{ M3 } & \multicolumn{3}{|l|}{ M4 } \\
\hline & Coef & $\mathrm{Se}$ & Sig & Coef & $\mathrm{Se}$ & Sig & Coef & $\mathrm{Se}$ & Sig & Coef & $\mathrm{Se}$ & Sig \\
\hline Incumbency & -0.13 & $(0.14)$ & & -0.30 & $(0.16)$ & $\dagger$ & -0.27 & $(0.18)$ & & -0.11 & $(0.08)$ & \\
\hline $\begin{array}{l}\text { Party member } \\
\text { of gvt }\end{array}$ & 0.39 & $(0.10)$ & $* * *$ & $=0.02$ & $(0.06)$ & & 0.02 & $(0.09)$ & & 0.22 & $(0.04)$ & $* * *$ \\
\hline Experience & -0.08 & $(0.06)$ & & -0.00 & $(0.03)$ & & -0.06 & $(0.04)$ & & -0.04 & $(0.03)$ & \\
\hline Left-right & -0.00 & $(0.02)$ & & 0.05 & $(0.01)$ & $* * *$ & 0.03 & $(0.01)$ & $*$ & 0.02 & $(0.01)$ & $*$ \\
\hline Extremism & -0.07 & $(0.03)$ & $*$ & -0.04 & $(0.02)$ & $*$ & -0.11 & $(0.02)$ & & $*-0.07$ & $(0.01)$ & $* * *$ \\
\hline $\begin{array}{l}\text { Distance from } \\
\text { party }\end{array}$ & 0.06 & $(0.04)$ & & 0.01 & $(0.03)$ & & -0.03 & $(0.03)$ & & 0.02 & $(0.02)$ & \\
\hline $\begin{array}{c}\text { Professional } \\
\text { campaign }\end{array}$ & -0.13 & $(0.17)$ & & 0.02 & $(0.09)$ & & 0.13 & $(0.19)$ & & -0.02 & $(0.08)$ & \\
\hline $\begin{array}{l}\text { Size of campaign } \\
\text { team }\end{array}$ & -0.00 & $(0.00)$ & & 0.00 & $(0.00)$ & & -0.00 & $(0.00)$ & & -0.00 & $(0.00)$ & \\
\hline $\begin{array}{l}\text { Perceived close- } \\
\text { ness of race }\end{array}$ & -0.05 & $(0.06)$ & & 0.06 & $(0.05)$ & & -0.01 & $(0.05)$ & & 0.00 & $(0.03)$ & \\
\hline $\begin{array}{l}\text { Campaign for } \\
\text { party not self }\end{array}$ & -0.04 & $(0.01)$ & $* *$ & -0.01 & $(0.01)$ & & -0.00 & $(0.01)$ & & -0.02 & $(0.01)$ & $* *$ \\
\hline Female & 0.11 & $(0.09)$ & & -0.26 & $(0.05)$ & $* * *$ & 0.15 & $(0.07)$ & $*$ & -0.01 & $(0.04)$ & \\
\hline Age & 0.01 & $(0.00)$ & $*$ & 0.00 & $(0.00)$ & $\dagger$ & 0.01 & $(0.00)$ & $*$ & 0.01 & $(0.00)$ & $* * *$ \\
\hline $\begin{array}{l}\text { Migration back- } \\
\text { ground }\end{array}$ & 0.04 & $(0.21)$ & & 0.06 & $(0.09)$ & & 0.01 & $(0.23)$ & & 0.04 & $(0.08)$ & \\
\hline Switzerland ${ }^{a}$ & & & & & & & & & & 0.64 & $(0.05)$ & $* * *$ \\
\hline Finland $^{\mathrm{a}}$ & & & & & & & & & & 0.25 & $(0.06)$ & $* * *$ \\
\hline Plasticity ${ }^{b}$ & -0.03 & $(0.07)$ & & -0.03 & $(0.04)$ & & 0.06 & $(0.06)$ & & 0.01 & $(0.03)$ & \\
\hline Stability $^{\mathrm{c}}$ & -0.10 & $(0.09)$ & & 0.04 & $(0.05)$ & & -0.02 & $(0.07)$ & & -0.02 & $(0.04)$ & \\
\hline Intercept & -0.98 & $(0.41)$ & $*$ & -0.99 & $(0.26)$ & $* * *$ & -1.51 & $(0.32)$ & $* * *$ & $*-1.44$ & $(0.18)$ & $* * *$ \\
\hline $\mathrm{N}$ & 653 & & & 1,508 & & & 578 & & & 2,739 & & \\
\hline $\mathrm{R} 2$ & 0.08 & & & 0.05 & & & 0.09 & & & 0.11 & & \\
\hline
\end{tabular}

All models are linear regressions. The dependent variable measures the use of character attacks instead of issue attacks and varies theoretically between -4 'high issue attacks and low character attacks' and +4 'high character attacks and low issue attacks.' All models weighted by party strength

${ }^{\text {a }}$ Reference category is Germany

${ }^{\mathrm{b}}$ Extraversion, openness

${ }^{\mathrm{c}}$ Agreeableness, conscientiousness, neuroticism (reversed)

$* * * p<0.001, * * p<0.01, * p<0.05,{ }^{\dagger} p<0.1$

the target can influence the use of attacks quite substantially (e.g., Ansolabehere \& Iyengar, 1995, pp.121-127; Maier \& Renner, 2018). Most notably, further research should strive to dig deeper into the relationship between two of the most prominent features of contemporary election campaigns: negative campaigning and personalization. While we showed that individual candidates' decision to go negative is driven, among other things, by their personalities, it would be interesting to investigate whether they personalize their targets by focusing their attacks on competing 
candidates rather than on other parties (and how this varies depending on the personality of the attacker and the target). Such behavior could well contribute to the recent trend toward "negative personalization" in voting behavior, where voters' party choice is increasingly shaped by their negative feelings about political candidates (e.g., Garzia \& da Silva 2021).

These limitations notwithstanding, our article makes an important contribution. Our analysis suggests that candidates run independent campaigns, even in Western European democracies, which have long been characterized by a party-centered campaign style (e.g., Plasser \& Plasser 2002). Our analysis shows that individual candidates make different use of negative campaigning, and that the decision to go negative (also) depends on their personalities.

Importantly, our findings apply to all three countries under study and are thus generally robust across different institutional settings, although some effects are slightly weaker or sometimes absent in one of the countries. This suggests that while institutional aspects might influence the decision to attack or not and hence the level of negativity across countries, they are unlikely to substantially alter the effects of personality traits on negative campaigning.

Supporting Information The online version of this article at https://doi.org/10.1057/s41269-021-00222-7.

Acknowledgements We wish to thank the journal editors and anonymous reviewers for their excellent comments and suggestions on our manuscript. All remaining mistakes are of course our responsibility alone. A previous version of the manuscript was presented during the 2020 (virtual) general conference of the European Consortium for Political Research (ECPR) and the 2021 (virtual) annual conference of the International Communication Association (ICA). A sincere thank you to Åsa von Schoultz for facilitating the use of the Finnish data.

Open Access This article is licensed under a Creative Commons Attribution 4.0 International License, which permits use, sharing, adaptation, distribution and reproduction in any medium or format, as long as you give appropriate credit to the original author(s) and the source, provide a link to the Creative Commons licence, and indicate if changes were made. The images or other third party material in this article are included in the article's Creative Commons licence, unless indicated otherwise in a credit line to the material. If material is not included in the article's Creative Commons licence and your intended use is not permitted by statutory regulation or exceeds the permitted use, you will need to obtain permission directly from the copyright holder. To view a copy of this licence, visit http://creativecommons.org/licen ses/by/4.0/.

\section{References}

Adam, S., and M. Maier. 2010. Personalization of politics a critical review and agenda for research. Annals of the International Communication Association 34 (1): 213-257.

Ansolabehere, S., S. Iyengar, A. Simon, and N. Valentino. 1994. Does attack advertising demobilize the electorate? American Political Science Review 88 (4): 829-838.

Bakker, B.N., and Y. Lelkes. 2018. Selling ourselves short? How abbreviated measures of personality change the way we think about personality and politics. The Journal of Politics. https://doi.org/10. $1086 / 698928$.

Benoit, W.L. 2007. Communication in political campaigns. New York: Oxford University Press.

Best, H. 2011. Does personality matter in politics? Personality factors as determinants of parliamentary recruitment and policy preferences. Comparative Sociology 10 (6): 928-948. 
Bono, J.E., and T.A. Judge. 2004. Personality and transformational and transactional leadership: A metaanalysis. Journal of Applied Psychology 89 (5): 901-910.

Brooks, D.J., and Geer, J.G. 2007. Beyond negativity: The effects of incivility on the electorate. American Journal of Political Science 51 (1): 1-16.

Carraro, L., and L. Castelli. 2010. The implicit and explicit effects of negative political campaigns: Is the source really blamed? Political Psychology 31 (4): 617-645.

De Hoogh, A.H., D.N. Den Hartog, and P.L. Koopman. 2005. Linking the Big Five-Factors of personality to charismatic and transactional leadership; perceived dynamic work environment as a moderator. Journal of Organizational Behavior 26 (7): 839-865.

de Vries, R.E., A. Bakker-Pieper, F.E. Konings, and B. Schouten. 2013. The communication styles inventory (CSI) a six-dimensional behavioral model of communication styles and its relation with personality. Communication Research 40 (4): 506-532.

DeYoung, C.G. 2006. Higher-order factors of the Big Five in a multi-informant sample. Journal of Personality and Social Psychology 91 (6): 1138-1151.

Dietrich, B.J., S. Lasley, J.J. Mondak, M.L. Remmel, and J. Turner. 2012. Personality and legislative politics: The Big Five trait dimensions among US state legislators. Political Psychology 33 (2): 195-210.

Digman, J.M. 1997. Higher-order factors of the Big Five. Journal of Personality and Social Psychology 73 (6): 1246-1256.

Elmelund-Præstekær, C. 2008. Negative campaigning in a multiparty system. Representation 44 (1): 27-39.

Ennser-Jedenastik, L., M. Dolezal, and W.C. Müller. 2017. Gender differences in negative campaigning: The impact of party environments. Politics \& Gender 13 (1): 81-106.

Fowler, E.G., M.M. Franz, and T.N. Ridout. 2016. Political advertising in the United States. Boulder: Westview Press.

Francia, P.L., and P.S. Herrnson. 2007. Keeping it professional: The influence of political consultants on candidate attitudes toward negative campaigning. Politics \& Policy 35 (2): 246-272.

Fridkin, K.L., and P.J. Kenney. 2011. Variability in citizens' reactions to different types of negative campaigns. American Journal of Political Science 55 (2): 307-325.

Fridkin, K.L., and P.J. Kenney. 2012. The impact of negative campaigning on citizens' actions and attitudes. In The Sage handbook of political communication, ed. H.A. Semetko and M. Scammell, 173185. Los Angeles: Sage.

Fridkin, K.L., and P. Kenney. 2019. Taking aim at attack advertising: Understanding the impact of negative campaigning in US Senate Races. New York: Oxford University Press.

Galasso, V., T. Nannicini, and S. Nunnari. 2020. Positive spillovers from negative campaigning. American Journal of Political Science. https://doi.org/10.1111/ajps.12610.

Garzia, D., and F. Ferreira da Silva. 2021. Negative personalization and voting behavior in 14 parliamentary democracies, 1961-2018. Electoral Studies 71 (2): 102300.

Geer, J.G. 2006. In defense of negativity: Attack ads in presidential campaigns. Chicago: University of Chicago Press.

Gerber, A.S., G.A. Huber, D. Doherty, and C.M. Dowling. 2011. The big five personality traits in the political arena. Annual Review of Political Science 14: 265-287.

Gerber, A.S., G.A. Huber, D. Doherty, C.M. Dowling, and S.E. Ha. 2010. Personality and political attitudes: Relationships across issue domains and political contexts. American Political Science Review 104 (1): 111-133.

Gosling, S.D., P.J. Rentfrow, and W.B. Swann. 2003. A very brief measure of the Big-Five personality domains. Journal of Research in Personality 37 (6): 504-528.

Haselmayer, M. 2019. Negative campaigning and its consequences: a review and a look ahead. French Politics 17 (3): 355-372.

Hills, P., and M. Argyle. 2001. Emotional stability as a major dimension of happiness. Personality and Individual Differences 31 (8): 1357-1364.

Hochwarter, W.A., L.A. Witt, and K.M. Kacmar. 2000. Perceptions of organizational politics as a moderator of the relationship between consciousness and job performance. Journal of Applied Psychology 85 (3): 472-478.

Holian, D.B., and C. Prysby. 2014. Candidate character traits in the 2012 Presidential election. Presidential Studies Quarterly 44 (3): 484-505.

Hopmann, D. N., Vliegenthart, R., and Maier, J. (2018). The effects of tone, focus, and incivility in election debates. Journal of Elections, Public Opinion and Parties 28 (3): 283-306. 
Iyengar, S., G. Sood, and Y. Lelkes. 2012. Affect, not ideology. A social identity perspective on polarization. Journal of Politics 76 (3): 405-431.

Jensen-Campbell, L.A., K.A. Gleason, R. Adams, and K.T. Malcolm. 2003. Interpersonal conflict, agreeableness, and personality development. Journal of Personality 71 (6): 1059-1086.

John, O.P., L.P. Naumann, and C.J. Soto. 2008. Paradigm shift to the integrative Big Five trait taxonomy: History, measurement, and conceptual issues. In Handbook of Personality: Theory and Research, ed. O.P. John, R.W. Robins, and L.A. Pervin, 114-158. New York: Guilford Press.

John, O.P., and S. Srivastava. 1999. The Big Five trait taxonomy: History, measurement, and theoretical perspectives. Handbook of Personality: Theory and Research 2 (1999): 102-138.

Joly, J., S. Soroka, and P. Loewen. 2019. Nice guys finish last: Personality and political success. Acta Politica 54 (4): 667-683.

Judge, T.A., C.A. Higgins, C.J. Thoresen, and M.R. Barrick. 1999. The big five personality traits, general mental ability, and career success across the life span. Personnel Psychology 52 (3): 621-652.

Karlsen, R. 2011. A platform for individualized campaigning? Social media and parliamentary candidates in the 2009 Norwegian Election Campaign. Policy \& Internet 3 (4): 4.

Karvonen, L. (2010). The personalisation of politics. A study of parliamentary democracies. Colchester: ECPR Press.

Lau, R.R., and G.M. Pomper. 2004. Negative campaigning. An analysis of U.S. Senate elections. Lanham: Rowman \& Littlefield.

Lijphart, A. 2012. Patterns of democracy. Government forms and performance in thirty-six countries. New Haven: Yale University Presse.

Lilienfeld, S.O., I.D. Waldman, K. Landfield, A.L. Watts, S. Rubenzer, and T.R. Faschingbauer. 2012. Fearless dominance and the US presidency: Implications of psychopathic personality traits for successful and unsuccessful political leadership. Journal of Personality and Social Psychology 103 (3): 489-505.

Lipsitz, K., C. Trost, M. Grossmann, and J. Sides. 2005. What voters want from political campaign communication. Political Communication 22: 337-354.

Lipsitz, K., and J.G. Geer. 2017. Rethinking the concept of negativity: An empirical approach. Political Research Quarterly 70 (3): 577-589.

Maier, J. (2015). Do female candidates feel compelled to meet sex-role expectations or are they as tough as men? A content analysis on the gender-specific use of attacks in German televised debates. In New perspectives on negative campaigning: why attack politics matters, ed. Nai, A. and Walter, A. S., 129-146. Colchester: ECPR Press.

Maier, J., and Jansen, C. 2017. When do candidates attack in election campaigns? Exploring the determinants of negative candidate messages in German televised debates. Party Politics 23 (5): 549-559.

Maier, J., and A. Nai. 2021. Mapping the drivers of negative campaigning: Insights from a candidate survey. International Political Science Review. https://doi.org/10.1177/0192512121994512.

Maier, J., and A.M. Renner. (2018). When a Man Meets a Woman: Comparing the Use of Negativity of Male Candidates in Single-and Mixed-Gender Televised Debates. Political Communication, 35(3): 433-449.

Makropoulos, I., S. Collignon, H. Giebler, W. Rüdig, J. Sajuria, and B. Weßels. 2021. Determinants of personalised campaigns. A comparative analysis. In Parliamentary candidates between voters and parties. A comparative perspective, ed. L. De Winter, R. Karlsen and H. Schmitt, 97-119. London: Routledge.

Moffitt, B. 2016. The global rise of populism: Performance, political style, and representation. Stanford: Stanford University Press.

Mondak, J.J., and D.K. Halperin. 2008. A framework for the study of personality and political behaviour. British Journal of Political Science 38 (2): 335-362.

Mondak, J.J., M.V. Hibbing, D. Canache, M.A. Seligson, and M.R. Anderson. 2010. Personality and civic engagement: An integrative framework for the study of trait effects on political behavior. American Political Science Review 104 (01): 85-110.

Mondak, J.J. 2010. Personality and the foundations of political behavior. Cambridge University Press.

Nai, A. 2019. Disagreeable narcissists, extroverted psychopaths, and elections. A new dataset to measure the personality of candidates worldwide. European Political Science 18 (2): 309-334.

Nai, A. 2020. Going negative, worldwide. Towards a general understanding of determinants and targets of negative campaigning. Government \& Opposition 55 (3): 430-455.

Nai, A. 2021. Fear and loathing in populist campaigns? Comparing the communication style of populists and non-populists in elections worldwide. Journal of Political Marketing 20 (2): 219-250. 
Nai, A., and Maier, J. 2018. Perceived personality and campaign style of Hillary Clinton and Donald Trump. Personality and Individual Differences 121: 80-83.

Nai, A., and Maier, J. 2019. Can anyone be objective about Donald Trump? Assessing the personality of political figures. Journal of Elections, Public Opinion \& Parties. https://doi.org/10.1080/17457289. 2019.1632318

Nai, A., and Maier, J. 2020. Dark necessities? Candidates' aversive personality traits and negative campaigning in the 2018 American Midterms. Electoral Studies. https://doi.org/10.1016/j.electstud. 2020.102233

Nai, A. and Martínez i Coma, F. 2019. The personality of populists: Provocateurs, charismatic leaders, or drunken dinner guests? West European Politics 42 (7): 1338-1367.

Nai, A., Martínez i Coma, F. and Maier, J. 2019. Donald Trump, populism, and the age of extremes: Comparing the personality traits and campaigning styles of Trump and other leaders worldwide. Presidential Studies Quarterly 49 (3): 609-643.

Newman, J.P. 1987. Reaction to punishment in extraverts and psychopaths: Implications for the impulsive behavior of disinhibited individuals. Journal of Research in Personality 21 (4): 464-480.

Plasser, F., and G. Plasser. 2002. Global political campaigning: A worldwide analysis of campaign professionals and their practices. London: Praeger.

Ramey, A.J., J.D. Klingler, and G.E. Hollibaugh. 2017. More than a feeling: Personality, polarization, and the transformation of the US congress. Chicago: University of Chicago Press.

Rammstedt, B., and O.P. John. 2007. Measuring personality in one minute or less: A ten-item short version of Big Five Inventory in English and German. Journal of Research in Personality 41: 203-212.

Roese, N.J., and G.N. Sande. 1993. Backlash effects in attack politics. Journal of Applied Social Psychology 23 (8): 632-653.

Schumacher, G., and I. Zettler. 2019. House of Cards or West Wing? Self-reported HEXACO Traits of Danish Politicians. Personality and Individual Differences 141: 173-181.

Scott, C., and M. Medeiros. 2020. Personality and political careers: What personality types are likely to run for office and get elected? Personality and Individual Differences 152: 109600.

Seibert, S.E., and M.L. Kraimer. 2001. The five-factor model of personality and career success. Journal of Vocational Behavior 58 (1): 1-21.

Selb, P., and G. Lutz. 2015. Lone fighters: Intraparty competition, interparty competition, and candidates' vote seeking efforts in open-ballot PR elections. Electoral Studies 39: 329-337.

Silvia, P.J., E.C. Nusbaum, C. Berg, C. Martin, and A. O’Connor. 2009. Openness to experience, plasticity, and creativity: Exploring lower-order, high-order, and interactive effects. Journal of Research in Personality 43 (6): 1087-1090.

Silvia, P.J., B.P. Winterstein, J.T. Willse, C.M. Barona, J.T. Cram, K.I. Hess, and C.A. Richard. 2008. Assessing creativity with divergent thinking tasks: Exploring the reliability and validity of new subjective scoring methods. Psychology of Aesthetics, Creativity, and the Arts 2 (2): 68.

Skaperdas, S., and B. Grofman. 1995. Modeling negative campaigning. American Political Science Review 89 (1): 49-61.

Spain, S.M., P. Harms, and J.M. LeBreton. 2014. The dark side of personality at work. Journal of Organizational Behavior 35 (S1): S41-S60.

Stanford, M. S., Houston, R. J., Mathias, C. W., Villemarette-Pittman, N. R., Helfritz, L. E., and Conklin, S. M. 2003. Characterizing aggressive behavior. Assessment 10 (2): 183-190.

Stückelberger, S. 2021. Mobilizing and chasing: The voter targeting of negative campaigning - Lessons from the Swiss case. Party Politics 27 (2): 341-350.

Vecchione, M., and G.V. Caprara. 2009. Personality determinants of political participation: The contribution of traits and self-efficacy beliefs. Personality and Individual Differences 46 (4): 487-492.

Von Schoultz, A. 2018. Electoral systems in context: Finland. In The Oxford Handbook of Electoral Systems, ed. E.S. Herron, R.J. Pekkanen, and M.S. Shugart, 601-626. New York: Oxford University Press.

Walter, A.S. 2013. Women on the battleground: Does gender condition the use of negative campaigning? Journal of Elections, Public Opinion \& Parties 23 (2): 154-176.

Walter, A.S. 2014. Choosing the enemy. Attack behaviour in a multiparty system. Party Politics 20 (3): 311-323.

Walter, A.S., and Nai, A. 2015. Explaining the Use of Attack Behaviour in the Electoral Battlefield: A Literature Overview. In New Perspectives on Negative Campaigning: Why Attack Politics Matters, ed. Nai. A. and Walter, A.S. (pp. 97-114). Colchester: ECPR Press. 
Wright, J.D., and M.F. Tomlinson. 2018. Personality profiles of Hillary Clinton and Donald Trump: Fooled by your own politics. Personality and Individual Differences 128: 21-24.

Walter, A.S., and W. van der Brug. 2013. When the gloves come off: Inter-party variation in negative campaigning in Dutch elections, 1981-2010. Acta Politica 48 (4): 367-388.

Publisher's Note Springer Nature remains neutral with regard to jurisdictional claims in published maps and institutional affiliations. 